JURNAL SEKRETARIS DAN ADMINISTRASI BISNIS

Journal homepage http tljurnal asmtbacid

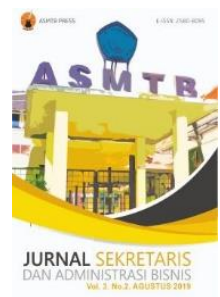

\title{
Pengaruh Experiential Marketing terhadap Customer Loyalty (Survei pada Konsumen Grab-Car di Kota Batam)
}

Arianis Chan ${ }^{1}$, Nindi Atikah Safira ${ }^{2}$, Rivani $^{3}$, Nurillah Jamil Achmawati Novel ${ }^{4}$

1,2,3,4 Universitas Padjadjaran

1 arianis.chan@unpad.ac.id; ${ }^{2}$ nindiatikahsafira@gmail.com; ${ }^{3}$ rivani@unpad.ac.id; ${ }^{4}$ nurillah11001@ mail.unpad.ac.id

\begin{tabular}{l}
\hline Article info \\
\hline Article history: \\
Received $26^{\text {th }}$ February 2021 \\
Received in revised form $22^{\text {nd }}$ July 2021 \\
Accepted $26^{\text {th }}$ August 2021 \\
\hline Keywords: \\
Marketing, \\
Experiential Marketing, \\
Customer Loyalty
\end{tabular}

Abstract
This research aims to find out about experiential marketing and
customer loyalty as well as the effect of experiential marketing on
customer loyalty in Grab-Car services. The objects examined in this
study is experiential marketing and customer loyalty.

The research method that used in this research is descriptive verification analysis and the design of research is survey. The sampling technique that used is non-probability sampling and done by using purposive sampling. This research used simple linear analysis to determine the effect of experiential marketing on customer loyalty in Grab-car services. Data sourced from literature study, observation, questionnaire and interview.

The population of this research is all Grab-Car consumers in Batam City. The sampling technique that used is non-probability sampling and done by using purposive sampling with the criteria of respondents is already using Grab-Car service in Batam City at least two times. The number of samples from this study was determined using iteration techniques with the acquisition of a sample size of one hundred thirty six respondents.

The results of this research shows that experiential marketing has a significant effect on customer loyalty Grab-Car services, which means that any increase in experiential marketing will cause an increase in customer loyalty. The author suggested is that Grab-Car makes think marketing strategies more attractive so that consumers can think deeper so they can provide a good opinion of the company's services.

Kata kunci:

Marketing,

Experiential Marketing,

Customer Loyalty
Penelitian ini bertujuan untuk mengetahui tentang experiential marketing dan customer loyalty serta pengaruh experiential marketing terhadap customer loyalty pada layanan Grab-car. Objek yang diteliti dalam penelitian ini adalah experiential marketing dan customer loyalty.

Metode penelitian yang digunakan adalah analisis deskriptif verifikatif dengan desain survei. Teknik pengambilan sampel dilakukan dengan non-probability sampling menggunakan purposive sampling. Penelitian ini menggunakan analisis linier sederhana untuk mengetahui pengaruh experiential marketing terhadap customer loyalty pada layanan Grab- 
Car. Data bersumber dari studi pustaka, observasi, kuisioner dan wawancara.

Populasi dari penelitian ini adalah seluruh konsumen Grab-Car di Kota Batam. Pengambilan sampel menggunakan metode non-probability sampling yaitu dengan menggunakan purposive sampling dengan kriteria responden telah menggunakan layanan Grab-Car di Kota Batam minimal sebanyak dua kali. Ukuran sampel dari penelitian ini ditentukan menggunakan teknik iterasi dengan perolehan jumlah sampel yaitu 116 responden.

Hasil penelitian ini menunjukan bahwa experiential marketing berpengaruh signifikan terhadap customer loyalty layanan Grab-Car yang artinya setiap kenaikan dari experiential marketing akan menyebabkan kenaikan customer loyalty. Saran yang penulis ajukan adalah Grab-Car membuat strategi think marketing yang lebih menarik sehingga konsumen dapat berfikir lebih dalam sehingga mampu memberikan opini yang bagus terhadap layanan dan service perusahaan.

@ 2021 ASMTB PRESS 


\section{PENDAHULUAN}

Perkembangan teknologi saat ini mendekatkan manusia dengan jaringan internet dalam berbagai aktivitas sehari-hari. Berdasarkan survei Asosiasi Penyelenggara Jaringan Internet (APJII) pada tahun 2018, terdapat 171,17 juta penduduk Indonesia yang telah terhubung oleh internet. Angka tersebut mengalami peningkatan dibandingkan jumlahnya pada tahun 2017 lalu sebanyak 143,27 juta pengguna.

Internet berkembang pesat dalam pemenuhan kebutuhan masyarakat akan akses informasi yang kini berkembang pula pada teknologi moda transportasi berbasis online. Transportasi online menjadi salah satu solusi terhadap berbagai kekurangan transportasi umum yang tersedia saat ini, terutama di Kota Batam, Selain jumlah pengguna internet cukup tinggi, tetapi juga sulitnya akses transportasi di Kota Batam menjadi alasan munculnya transportasi umum berbasis online tersebut. Hal tersebut juga salah satunya disebabkan posisi Kota Batam di wilayah perbatasan yang menjadikan transportasi menjadikan salah satu tantangan bagi berbagai sektor (Andini \& Akbar, 2020).

Salah satu jenis transportasi online yang hadir di Kota Batam adalah Grab yang merupakan platform O2O (Online to Offline) menyediakan layanan kebutuhan sehari-hari, termasuk jasa perjalanan. Grab memberikan layanan bagi penumpang dengan menekankan pada kecepatan, keselamatan, dan kepastian. Meski tantangannya hampir sama seperti di berbagai daerah lainnya Grab, khususnya Grab Car, dianggap masalah bagi taksi konvensional yang telah beroperasi lebih dulu di Kota Batam. Selain itu, Grab juga bersaing dengan penyedia layanan taksi online sejenis sehingga harus mempertahankan pelanggannya agar tetap loyal dan tidak berpindah ke layanan taksi online lainnya.

Banyak perusahaan yang menawarkan variasi layanan sejenis memperketat persaingan, Grab memerlukan suatu strategi sebagai bentuk diferensiasi perusahaan dalam menarik minat konsumen sehingga dapat mempertahankan pelanggan agar tetap loyal menggunakan jasa perusahaan Grab-Car di masa sekarang dan yang akan datang (Chan, Maharani, \& Tresna, 2017).

Menurut Wong (Ekasari, 2015), pengalaman merupakan alat pembeda suatu produk atau jasa atau disebut juga dengan experiental marketing yang merupakan upaya pengembangan konsep pemasaran dalam menghadapi perubahan di pasar (Ekasari, 2015).

Grab turut melibatkan pelanggan dalam produknya, melalui aplikasi yang memberikan berbagai pelayanan dengan mudah dan sesuai dengan kebutuhan. Hal ini memberikan pengalaman baru bagi pelanggan pada layanan transportasi umum berbasis online yang lebih nyaman, aman, kepastian harga.

Fenomena-fenomena yang telah diuraikan di atas menarik peneliti untuk melakukan penelitian yang berjudul "Pengaruh Experiental Marketing terhadap Customer Loyalty (Survei pada Konsumen GrabCar di Kota Batam)". 


\subsection{Experiental Marketing}

Experiental Marketing (Fyall, Legohérel, Frochot, \& Wang, 2019) memandang konsumen sebagai manusia rasional dan emosional yang peduli dengan pencapaian pengalaman yang menyenangkan. Lima jenis pengalaman berbeda, atau strategic experiential modules (SEM), yang dapat diciptakan pemasar untuk pelanggan dibedakan: pengalaman sensorik (SENSE); pengalaman afektif (FEEL); pengalaman kognitif kreatif (THINK); pengalaman fisik, perilaku dan gaya hidup (ACT); dan pengalaman identitas sosial yang dihasilkan dari hubungan dengan kelompok referensi atau budaya (RELATE). Pengalaman ini diimplementasikan melalui apa yang disebut penyedia pengalaman seperti komunikasi, identitas visual dan verbal, kehadiran produk, media elektronik, dan lain-lain.

Dimensi experiential marketing meliputi 5 (lima) tipe pengalaman pelanggan yaitu sense, feel, think, ach, dan relate ((Schmitt in Fyall et al., 2019).

\section{a) Sense (Pengalaman Indera)}

Sense berfokus pada perasaan dengan tujuan untuk menciptakan pengalaman melalui panca indera yaitu, sight (penglihatan), sound (suara), taste (rasa), touch (sentuhan), dan smell (aroma).

\section{b) Feel (Pengalaman Afektif)}

Feel berusaha menarik perasaan terdalam dan emosi pelanggan dengan tujuan untuk menciptakan perasaan yang dalam terhadap pengalaman pelanggan yang di dapat.

\section{c) Think (Pengalaman Kognitif Kreatif)}

Tujuan dari think marketing ini memang untuk membawa pelanggan mampu berfikir lebih dalam dan kreatif sehingga memberikan opini yang bagus terhadap produk dan service perusahaan.

\section{d) Act (Pengalaman Fisik dan Gaya Hidup)}

Act marketing dirancang untuk menciptakan pengalaman yang berhubungan dengan pengalaman tubuh (physical/body), pola perilaku jangka panjang dan gaya hidup, serta pengalaman sebagai hasil interaksi dengan orang lain, yang akan memperkaya kehidupan pelanggan dengan pengalaman yang bersifat ragawi

\section{e) Relate (Pengalaman Identitas Sosial)}

Relate marketing sering kali terjadi akibat dari sense, feel, think dan act experience. Relate dikembangkan diluar hubungan personal dan perasaan pribadi tetapi menambah pengalaman individual dalam hubungan dengan orang lain. 


\subsection{Customer Loyalty}

"Loyalitas pelanggan lebih mengacu pada wujud perilaku dari unit-unit pengambilan keputusan untuk melakukan pembelian secara terus menerus terhadap barang atau jasa suatu perusahaan yang dipilih". (Griffin, 2005)

Adapun dimensi customer loyalty dijelaskan melalui beberapa karakteristik pelanggan yang loyal berikut ini.

\section{a) Melakukan pembelian ulang secara teratur}

Artinya pembelian secara regular kontinuitas pelanggan dalam melakukan pembelian atau konsumsi atas produk yang ditawarkan oleh perusahaan.

\section{b) Membeli antarlini produk dan jasa}

Artinya pembelian yang dilakukan oleh pelanggan atas berbagai lini produk perusahaan.

\section{c) Mereferensikan kepada orang lain}

Kesediaan pelanggan dalam memberikan referensi kepada pihak lain untuk mengkonsumsi produk.

\section{d) Menunjukkan kekebalan terhadap tarikan dari pesaing}

Artinya kekebalan atau tidak terdapatnya ketertarikan pelanggan terhadap pelayanan sejenis dan bentukbentuk promosi pesaing. Hal ini berhubungan dengan perhatian pelanggan tentang apa yang dilakukan oleh perusahaan berkaitan dengan layanan produk atau jasa yang dirasa memuaskan.

\section{METODE PENELITIAN}

\subsection{Objek Penelitian dan Metode}

Objek dari penelitian ini adalah experiential marketing sebagai variabel (independen) dan yang sebagai variabel (dependen) meliputi customer loyalty. Penelitian ini dilakukan terhadap konsumen Grab-Car di Kota Batam.

Metode yang digunakan adalah survei yang biasanya digunakan untuk mendapatkan suatu generalisasi suatu pengamatan yang tidak mendalam namun lebih akurat apabila sampel yang digunakan representatif (Riduwan, 2007).

Pengambilan data primer dilakukan melalui wawancara dan kuesioner terhadap konsumen Grab-car di Kota Batam. Sedangkan data penunjang diperoleh dari studi pustaka dan observasi dari berbagai sumber.

\subsection{Populasi dan Sampel}

Populasi dalam penelitian ini adalah seluruh konsumen Grab-car di Kota Batam. Sedangkan jumlah sampel ditentukan menggunakan teknik iterasi (Singarimbun, 2006) karena jumlah populasi tidak dapat diketahui secara pasti. Berdasarkan pertungan iteratif sebanyak dua kali yang menunjukkan hasil yang konsisten, maka ukuran sampel yang harus diambil adalah minimum 116 orang responden konsumen Grab-Car di Kota Batam. 


\subsection{Uji Validitas}

Kuesioner pada penelitian ini terdiri dari 47 pernyataan yang dilakukan uji validitas melalui pengolahan SPSS. Hasil perhitungan dengan $\alpha=5 \%$ dan n sebanyak 30 menunjukkan semua pertanyaan kuesioner memiliki nilai rhitung > rtabel. Diperoleh nilai $r_{\text {tabel }}$ sebesar 0,361 lebih kecil daripada $\mathrm{r}_{\text {hitung }}$ dari seluruh item pernyataan kuesioner yang berarti kuesioner yang digunakan penelitian ini adalah valid/ sah.

\subsection{Uji Reliabilitas}

Uji reliabilitas yang digunakan adalah uji Cronbach's Alpha. Dari hasil pengujian nilai Cronbach's Alpha untuk variabel experiential marketing (X) sebesar 0,970 dan untuk variabel customer royalty (Y) sebesar 0,725. Hal ini dinyatakan bahwa desain kuesioner Experiental Marketing dan customer loyalty tersebut reliabel karena nilai Cronbach's Alpha masuk pada kategori andal dan sangat andal.

\subsection{Analisis Data}

Untuk mengetahui pengaruh experiential marketing (X) terhadap customer loyalty (Y), maka metode analisis yang digunakan adalaj uji normalitas, regresi linier sederhana, koefisien determinasi, dan pengujian hipotesis.

\section{HASIL DAN DISKUSI}

\subsection{Deskripsi Variabel Experiential Marketing (X)}

Tabel 1. Rekapitulasi Skor pada Variabel Experiental Marketing

\begin{tabular}{|c|c|c|c|c|}
\hline No & Dimensi & Skor & $\begin{array}{c}\text { Skor } \\
\text { Maks }\end{array}$ & $\%$ \\
\hline 1 & Sense (Pengalaman Indera) & 5531 & 7480 & 73,94 \\
\hline 2 & Feel (Pengalaman Afektif) & 6283 & 8160 & 77,00 \\
\hline 3 & Think (Pengalaman Kognitif Kreatif) & 4838 & 6120 & 79,05 \\
\hline 4 & Act (Pengalaman Fisik dan Gaya Hidup) & 4238 & 5440 & 77,90 \\
\hline 5 & Relate (Pengalaman Identitas Sosial) & 1499 & 2040 & 73,48 \\
\hline \multicolumn{2}{|c|}{ Jumlah } & 22389 & 29240 & 76,57 \\
\hline
\end{tabular}

Sumber : Data Penelitian 2019

Dari tabel di atas, diketahui bahwa skor jawaban sebesar 22389 untuk 43 pernyataan yang diberikan, nilai tertinggi diberi skor 5 dan nilai terendah diberi skor 1, maka:

- Skor minimum: $1 \times 43 \times 136=5848$

- Skor maksimum: $5 \times 4$ x136 =29240

- Range: $29240-5848=23392$

- Panjang Interval: 23392:5=4678,4 
Interval kategori untuk skor jawaban variabel experiental marketing adalah sebagai berikut:

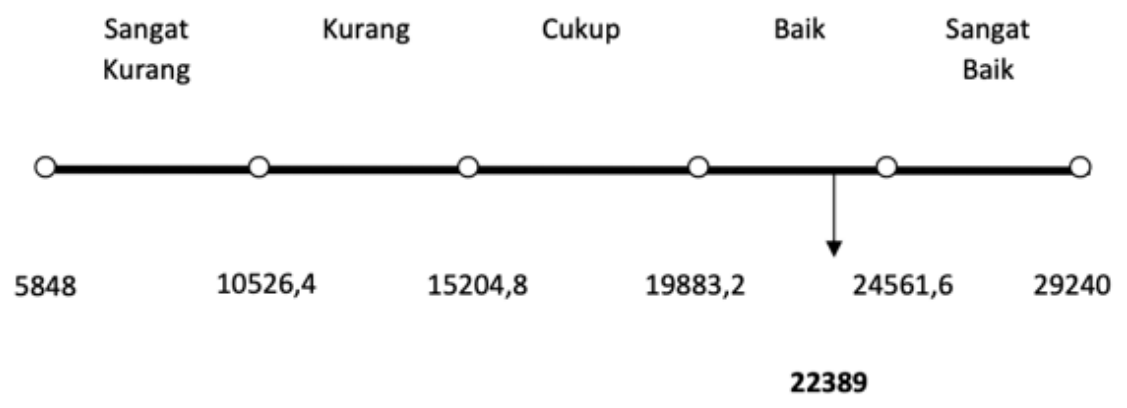

Gambar 1. Kategori Variabel Experiental Marketing

Data pada garis kontinom di atas menunjukkan bahwa experiental marketing berada pada kategori baik. Dengan demikian, tampak bahwa sebagian besar responden memiliki experiental marketing yang baik. Hal ini tampak pada persepsi 136 responden yang setelah dianalisis mencapai 22389 atau 76,57\%. Berdasarkan data pada garis kontinum diatas membuktikan bahwa layanan Grab-Car di Kota Batam terbilang baik dalam memberikan memorable experience kepada konsumennya dengan unsur sense (pengalam indera), feel (pengalaman afektif), think (pengalaman kognitif kreatif), act (pengalaman fisik dan gaya hidup), serta relate (pengalaman identitas sosial) sehingga mampu meyentuh hati dan perasaan konsumen secara positif.

\subsection{Deskripsi Variabel Customer Loyalty (Y)}

Tabel 2. Rekapitulasi Skor pada Variabel Customer Loyalty

\begin{tabular}{|c|l|c|c|c|}
\hline No & \multicolumn{1}{|c|}{ Dimensi } & Skor & $\begin{array}{c}\text { Skor } \\
\text { Maks }\end{array}$ & $\%$ \\
\hline 1 & Melakukan pembelian berulang secara teratur & 549 & 680 & 80,74 \\
\hline 2 & Membeli antar lini produk atau jasa & 543 & 680 & 79,85 \\
\hline 3 & Mereferensikan kepada orang lain & 496 & 680 & 72,94 \\
\hline 4 & Menunjukkan kekebalan terhadap tarikan pesaing & 378 & 680 & 55,59 \\
\hline \multicolumn{2}{r|}{ Jumlah } & 1966 & 2720 & 72,28 \\
\hline
\end{tabular}

Sumber: Data Penelitian 2019

Dari tabel di atas, diketahui bahwa skor jawaban sebesar 1966 untuk 4 pernyataan yang diberikan, nilai tertinggi diberi skor 5 dan nilai terendah diberi skor 1, maka:

- Skor minimum: $1 \times 4 \times 136=544$

- Skor maksimum: 5 x 4 x $136=2720$

- Range: $2720-544=2176$

- Panjang Interval: $2176: 5=435,2$ 
Interval kategori untuk skor jawaban dimensi customer loyalty adalah sebagai berikut:

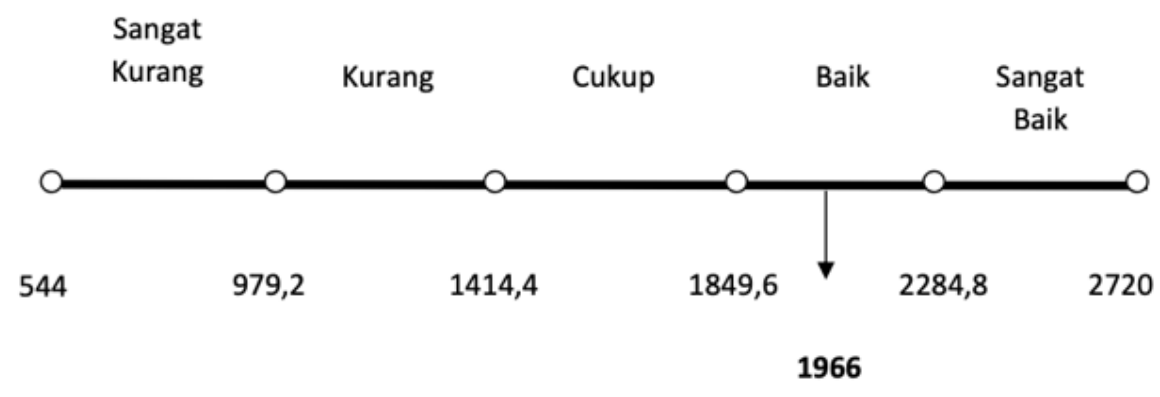

Gambar 2 Kategori Variabel Customer Loyalty

Data pada garis kontinom di atas menunjukkan bahwa customer loyalty berada pada kategori baik. Dengan demikian, tampak bahwa sebagian besar responden memiliki customer loyalty yang baik. Hal ini tampak pada persepsi 136 responden yang setelah dianalisis mencapai 1966 atau 72,28\%. Hal ini menunjukan bahwa customer loyalty yang dimiliki Grab-Car di Kota Batam sudah baik dengan dimensi customer loyalty yang terdiri dari empat dimensi yaitu melakukan pembelian berulang secara teratur, membeli antar lini produk atau jasa, mereferensikan kepada orang lain, dan menunjukkan kekebalan terhadap tarikan pesaing.

\subsection{Analisis Regresi Linier 4.3.1 Uji Asumsi Klasik}

Uji asumsi klasik yang harus dipenuhi sebelum analisis regresi linear sederhana dapat dilakukan, yaitu uji normalitas residual. Dalam melakukan pengujian asumsi klasik, peneliti menggunakan bantuan software SPSS.

\section{a. Uji Normalitas Data}

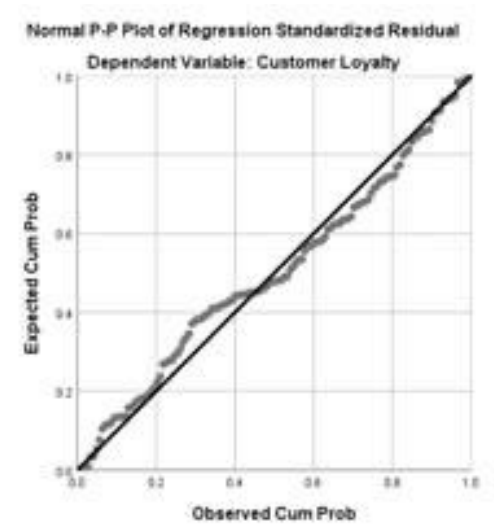

Gambar 3 Grafik P-P Plot Uji Normalitas Residual

Sumber: Hasil Pengolahan SPSS, tahun 2019 
Diketahui jika e $\sim \mathrm{N}(1,0)$ berdistribusi normal apabila sebaran unstandardized residual menyebar di sekitar garis diagonal dan mengikuti arah garis diagonal. Berdasarkan P-P plot pada gambar 4.12 dapat diketahui bahwa sebaran unstandardized residual mengikuti dan menyebar disekitar garis diagonal, maka dapat disimpulkan bahwa residu model persamaan regresi berdistribusi normal atau memenuhi asumsi normalitas. Untuk lebih meyakinkan bahwa residual berdistribusi normal maka dilakukan pengujian secara statistik dengan menggunakan uji Kolmogorov Smirnov.

Tabel 3. Hasil Uji Kolmogorov Smirnov

One-Sample Kolmogorov-Smirnov Test

\begin{tabular}{|c|c|c|}
\hline \multicolumn{3}{|c|}{ One-Sample Kolmogorov-Smirnov Test } \\
\hline & & $\begin{array}{l}\text { Unstandardized } \\
\text { Residual }\end{array}$ \\
\hline \multicolumn{2}{|l|}{$\mathrm{N}$} & 63 \\
\hline \multirow{2}{*}{$\begin{array}{l}\text { Normal } \\
\text { Parameters }{ }^{\mathrm{a}, \mathrm{b}}\end{array}$} & Mean & 1,2327 \\
\hline & $\begin{array}{l}\text { Std. } \\
\text { Deviation }\end{array}$ & 0,54563 \\
\hline \multirow{3}{*}{$\begin{array}{l}\text { Most } \\
\text { Extreme } \\
\text { Differences }\end{array}$} & Absolute & 0,082 \\
\hline & Positive & 0,082 \\
\hline & Negative & $-0,043$ \\
\hline \multicolumn{2}{|l|}{ Test Statistic } & 0,082 \\
\hline \multicolumn{2}{|c|}{ Asymp. Sig. (2-tailed) } & $.200^{\mathrm{c}, \mathrm{d}}$ \\
\hline
\end{tabular}

a) Test distribution is Normal.

b) Calculated from data.

c) Lilliefors Significance Correction.

d) This is a lower bound of the true significance.

Berdasarkan hasil pengujian Kolmogorov Smirnov di atas, di dapat p-value (asymp.sig 2-tailed) 0,200. Pengujian akan menolak H0 jika p-value $<\alpha(0,05)$. Hasil pengujian menunjukkan $p$-value lebih besar dari $\alpha(0,05)$ maka asumsi bahwa residual berdistribusi normal telah terpenuhi. 


\subsection{Pengujian Hipotesis}

\subsubsection{Korelasi Pearson}

Tabel 4. Hasil Perhitungan Koefisien Korelasi Pearson

\begin{tabular}{|c|c|c|c|}
\hline \multicolumn{4}{|c|}{ Correlations } \\
\hline & & $\begin{array}{c}\text { Experiential } \\
\text { Marketing }\end{array}$ & $\begin{array}{c}\text { Customer } \\
\text { Loyalty }\end{array}$ \\
\hline \multirow[t]{3}{*}{$\begin{array}{l}\text { Experiential } \\
\text { Marketing }\end{array}$} & $\begin{array}{l}\text { Pearson } \\
\text { Correlation }\end{array}$ & 1 & $.541^{* *}$ \\
\hline & $\begin{array}{l}\text { Sig. (2- } \\
\text { tailed) }\end{array}$ & & 0,000 \\
\hline & $\mathrm{N}$ & 136 & 136 \\
\hline \multirow[t]{3}{*}{$\begin{array}{l}\text { Customer } \\
\text { Loyalty }\end{array}$} & $\begin{array}{l}\text { Pearson } \\
\text { Correlation }\end{array}$ & $.541^{* *}$ & 1 \\
\hline & $\begin{array}{l}\text { Sig. (2- } \\
\text { tailed) }\end{array}$ & 0,000 & \\
\hline & $\mathrm{N}$ & 136 & 136 \\
\hline
\end{tabular}

**. Correlation is significant at the 0.01 level (2tailed).

Sumber: Hasil Pengolahan SPSS, tahun 2019

Berdasarkan hasil pengujian korelasi Pearson diatas, dapat dilihat koefisien korelasi Pearson sebesar 0,541 dimana bernilai positif dengan nilai $p$-value (Sig. 2 - tailed) sebesar $0,000<\alpha(0,05)$ maka H0 ditolak artinya ada hubungan yang searah antara experiental marketing dengan customer loyalty.

\subsubsection{Koefisien Determinasi (R Square)}

Tabel 5 Hasil Perhitungan Koefisien Determinasi

\begin{tabular}{|l|r|r|r|r|}
\hline \multicolumn{1}{|c|}{ Model Summary $^{\text {Model }}$} & R & R Square & $\begin{array}{r}\text { Adjusted } \\
\text { R Square }\end{array}$ & $\begin{array}{c}\text { Std. Error } \\
\text { of the } \\
\text { Estimate }\end{array}$ \\
\hline 1 & $.541^{\text {a }}$ & 0,293 & 0,287 & 2,30820 \\
\hline
\end{tabular}
a. Predictors: (Constant), Experiental Marketing
b. Dependent Variable: Customer Loyalty

Sumber: Hasil Pengolahan SPSS, tahun 2019

Berdasarkan tabel di atas, koefisien determinasi $\left(\mathrm{R}^{2}\right)$ adalah 0,293 maka dapat disimpulkan bahwa variabel experiential marketing memiliki kontribusi sebesar $29,30 \%$ pengaruhnya pada variabel customer loyalty dimana nilai tersebut dalam tabel 3.6 masuk ke dalam kategori rendah. Sedangkan sisanya sebesar $70,70 \%$ dijelaskan oleh variabel lain yang tidak diteliti dalam penelitian ini. 


\subsubsection{Pengujian Signifikansi Parameter Individual (Uji Statistik t)}

Pengujian statistik t bertujuan untuk melihat seberapa jauh pengaruh satu variabel independen terhadap variabel dependen. Dalam pengujian ini jika $\mathrm{t}$ hitung $>\mathrm{t}$ tabel atau signifikansi $\mathrm{t}$ hitung $(p$-value $)<\alpha$, maka ini berarti terdapat pengaruh yang signifikan secara statistik antara variabel independen tersebut terhadap variabel dependen. Nilai t tabel untuk jumlah sampel pada penelitian ini dan tingkat $\alpha=0,05$ adalah sebesar 1,97783 .

Hipotesis:

$\mathrm{H} 0: \beta_{1}=0$; Tidak terdapat pengaruh experiental marketing terhadap Customer loyalty pengguna layanan

Grab-Car

$\mathrm{H} 1: \beta_{1}=0$; Terdapat pengaruh experiental marketing terhadap Customer loyalty pengguna layanan Grab-Car

Taraf Signifikansi: $\alpha=5 \%$ atau 0,05

Kriteria pengujian hipotesis: tolak H0 jika t hitung $>$ t tabel atau t hitung $<-$ ttabel atau apabila Sig. $<\alpha$.

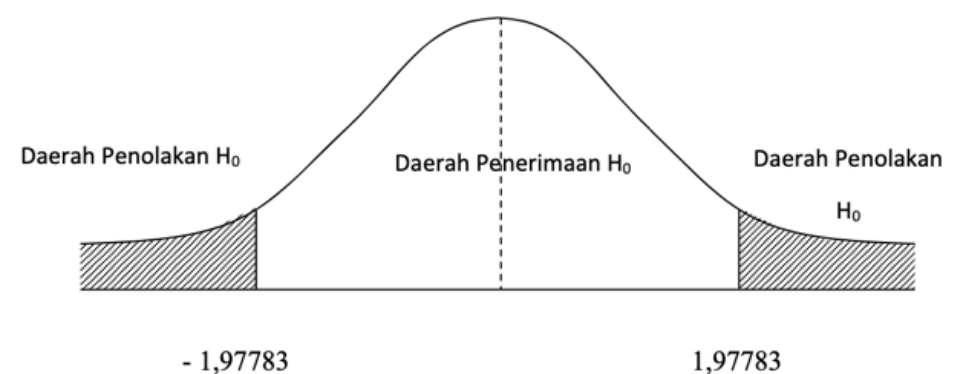

\section{Gambar 4. Kurva Uji Signifikan Koefisien Jalur X1 dengan Uji Dua Pihak}

Hasil perhitungan uji t adalah sebagai berikut:

Tabel 6 Hasil Uji Statistik t

\begin{tabular}{|c|c|c|c|c|c|c|}
\hline \multicolumn{7}{|c|}{ Coefficients $^{\mathrm{a}}$} \\
\hline & & \multicolumn{2}{|c|}{$\begin{array}{l}\text { Unstandardized } \\
\text { Coefficients }\end{array}$} & \multirow{2}{*}{$\begin{array}{c}\begin{array}{c}\text { Standardized } \\
\text { Coefficients }\end{array} \\
\text { Beta }\end{array}$} & \multirow[b]{2}{*}{$\mathrm{T}$} & \multirow[b]{2}{*}{ Sig. } \\
\hline \multicolumn{2}{|c|}{ Model } & B & Std. Error & & & \\
\hline \multirow[t]{2}{*}{1} & (Constant) & 4,295 & 1,203 & & 3,570 & 0,000 \\
\hline & $\begin{array}{l}\text { Experiental } \\
\text { Marketing }\end{array}$ & 0,062 & 0,008 & 0,541 & 7,448 & 0,000 \\
\hline
\end{tabular}


Dari tabel tersebut maka diperoleh nilai parameter konstanta dan nilai parameter penduga untuk melengkapi model regresi yang sudah dirumuskan sebelumnya. Persamaan regresi linear (model regresi) yang terbentuk adalah sebagai berikut:

$Y=4,295+0,062 X$

Pada persamaan di atas, koefisien intersep (konstanta) sebesar 4,295 menunjukkan besarnya customer loyalty tanpa pengaruh experiental marketing. Koefisien regresi untuk X sebesar 0,062 menunjukkan setiap peningkatan 1 satuan experiental marketing maka akan meningktkan customer loyalty sebesar 0,062 .

Dari hasil uji signifikansi pada tabel diatas. Diperoleh nilai t hitung sebesar 7,448 > t-tabel $(1,97783)$ atau Sig. $<\alpha(0,05)$ sehingga $\mathrm{H} 0$ ditolak dan $\mathrm{H} 1$ diterima, atau dapat disimpulkan bahwa experiental marketing mempunyai pengaruh secara signifikan terhadap customer loyalty pengguna layanan Grab-Car.

Hasil tersebut menunjukan bahwa experiential marketing memiliki pengaruh terhadap customer loyalty pada konsumen Grab-Car di Kota Batam walaupun pengaruhnya rendah.

\section{KESIMPULAN DAN SARAN}

\subsection{Kesimpulan}

Berdasarkan hasil analisis data yang telah dibahas, maka dapat disimpulkan beberapa hal di bawah ini:

1. Experiential marketing memperoleh kategori baik yang diukur melalui lima dimensi, yatu sense, feel, think, act, dan relate. Kelima dimensi tersebut berada pada kategori baik, dengan dimensi think memiliki presentase tertinggi. Sehingga, dapat diartikan bahwa responden setuju bahwa experiential marketing yang dilakukan Grab-Car di Kota Batam sudah baik.

2. Customer loyalty memperoleh kategori baik yang diukur melalui empat dimensi, yaitu melakukan pembelian berulang secara teratur, membeli antar lini produk atau jasa, mereferensikan kepada orang lain, dan menunjukkan kekebalan terhadap tarikan pesaing. Keempat dimensi tersebut berada pada kategori baik dan cukup, dengan dimensi melakukan pembelian berulang secara teratur yang memperoleh presentase tertinggi. Sehingga, dapat diartikan bahwa responden sudah memiliki customer loyalty yang baik terhadap Grab-Car di Kota Batam. 
3. Terdapat pengaruh yang rendah dari experiential marketing terhadap customer loyalty pada layanan Grab-Car di Kota Batam dengan persentase sebesar 29,30\%. 70,70\% sisanya dipengaruhi oleh faktor lain yang tidak diteliti.

\subsection{Saran}

Selain itu, peneliti juga memberikan beberapa saran berdasarkan kesimpulan yang diperoleh dari penelitian ini, yaitu sebagai berikut:

1. Guna meningkatkan pengalaman think dalam experiential marketing, penulis menyarankan agar pihak Grab mampu menciptakan dan atau memberikan bentuk- bentuk promosi atau penawaran menarik yang diciptakan melalui games (mengumpulkan poin untuk mendapatkan potongan harga, memberikan misi tertentu untuk mengumpulkan poin tersebut, mengadakan daily mission untuk meraih poin dalam mendapatkan potongan harga) agar konsumen dapat merasa tertantang dalam berpikir lebih dalam dan untuk menciptakan kekebalan konsumen terhadap tarikan pada pesaing lainnya.

2. Guna meningkatkan pengalaman relate (pengalaman identitas sosial), penulis menyarakan agar pihak Grab mampu memperkenalkan layanan saran dan kritik yang dimiliki yaitu customer service agar konsumen dapat merasakan tanggapan secara langsung terkait saran dan kritik yang diberikan kepada Grab terkait produk layanannya.

3. Guna meningkatkan pengalaman sense (pengalaman indera), penulis menyarankan agar Grab mampu memberikan fasilitas penunjang seperti menyediakan tissue, air minum, permen dan sebagainya untuk meningkatkan pengalaman indera yang jauh lebih baik kepada konsumen.

4. Penulis menyarankan pihak Grab untuk memberikan pelatihan secara berkala kepada driver, sehingga dengan adanya pelatihan secara berkala pihak Grab dapat dengan mudah me-maintance driver-nya dan dapat memberikan nilai lebih kepada konsumennya sesuai dengan tujuan dan iktisar kode etik yang dibawa oleh Grab itu sendiri.

5. Penulis menyarankan agar pihak Grab bekerja sama dengan pihak Pemerintah Kota Batam untuk mengadakan sosialisasi terkait pendapatan serta manfaat yang akan diperoleh bagi pihak driver taksi konvensional. 


\section{DAFTAR PUSTAKA}

Andini, C., \& Akbar, D. (2020). Tantangan Pariwisata pada Wilayah Perbatasan dalam Era Disrupsi Teknologi: Studi Kasus Regulasi Transportasi Online di Kota Batam, Kepulauan Riau. Indonesian Journal of Tourism and Leisure, 1(2). https://doi.org/10.36256/ijtl.v1i2.102

Chan, A., Maharani, M., \& Tresna, P. W. (2017). Perbandingan Pengalaman Pengguna Pada Aplikasi Mobile Go-Jek Dan Grab (Studi Pada Konsumen Pt Go-Jek Dan Pt Grab Indonesia Di Dki Jakarta). AdBispreneur, 2(2). https://doi.org/10.24198/adbispreneur.v2i2.13183

Ekasari, N. (2015). Pengaruh Experiential Marketing Terhadap Loyalitas Pelanggan Klinik Perawatan Kulit Natasha Kota Jambi. Jurnal Penelitian Universitas Jambi Seri Humaniora.

Fyall, A., Legohérel, P., Frochot, I., \& Wang, Y. (2019). Experiential marketing. In Marketing for Tourism and Hospitality (pp. 127-148). https://doi.org/10.4324/9781315651026-11

Griffin, J. (2005). Customer Loyalty: Menumbuhkan dan Mempertahankan Kesetiaan Pelanggan. Alih Bahasa Dr. Dwi Kartini Yahya. Jurnal Administrasi Bisnis (JAB).

Riduwan. (2007). Skala Pengukuran Variabel-variabel Penelitian. In Alfabeta, Bandung.

Schmitt, B. (1999). Experiential marketing, How to get customers to sense, feel, think, act, and relate to your company and brands. New York.

Singarimbun, M. (2006). Metode Penelitian Survai. In LP3ES.

Wong, 2005, "Experience Lost”, Marketing, Toronto, Vol 110, 1ss.22, p.11 http://pro quest.umi.com/pqdweb?did=857881791\&sid=1\&Fmt=3\&clientId=72459\&RQT=309\&VNa me=PQD 